\title{
Implementasi Metode Cerita Islami dalam Menanamkan Moral Keagamaan Siswa di MIS Nurul Islam Seresam
}

\author{
${ }^{1}$ Dessy Syofiyanti, ${ }^{2}$ Dian Purnomo \\ STAI Madinatun Najah Rengat \\ dessysyofiyanti@gmail.com
}

\begin{abstract}
ABSTRAK
Penelitian ini merujuk pada survey awal yang peneliti temukan, yakni adanya siswa yang melanggar moral keagamaan di sekolah, seperti merokok disaat jam pelajaran, mencuri di parkiran sekolah, bolos pada jam pelajaran, berkata kasar dan sebagainya. Terkait dengan permasalah ini, maka tujuan penelitian ini adalah untuk menyelesaikan masalah ini dengan menanamkan moral keagamaan kepada siswa dengan metode cerita Islami. Penelitian ini menggunakan metode kualitatif dengan pendekatan penelitian tindakan kelas studi kasus model Kurt Lewin. Instumen yang digunakan ialah metode observasi, wawancara. Informan penelitian Kepala Madrasah (1 orang), Guru (2 orang), Siswa (4 orang). Teknik analisa data dalam penelitian ini menggunakan model Miles dan Huberman. Hasil implementasi metode cerita Islami dalam menanamkan moral keagamaan di MIS Nurul Islam Seresam ditemukan perubahan-perubahan moral siswa yang terjadi di lingkungan sekolah seperti, siswa mulai sering melaksanakan sholat di sekolah. Siswa mulai berinterasi dengan baik kepada guru dan teman sebaya, siswa mulai menunjukan sikap bertanggung jawab, disiplin, dan sikap jujur. Kelebihan implementasi metode cerita Islami yakni, cerita dapat mengaktifkan dan membangkitkan semangat siswa, mengarahkan emosional siswa secara baik.
\end{abstract}

Kata kunci : Metode Cerita, Menanamkan Moral Keagamaan, Siswa (MIS)

\begin{abstract}
This research refers to the initial survey that researchers find, that is, students who violate religious moral in schools, such as smoking at the time of lesson, steal the parking of the school, skip in the lesson hours, said rude and so on. Related to this problem, the purpose of this research is to solve this problem by embedding religious moral to students with Islamic story method. The study used qualitative methods with the research approach of Action class case study model Kurt Lewin. The instruments used are observation methods, interviews. Research informant of Madrasah (1 person), teacher (2 people), student (4 people). The data analysis techniques in this study use the Miles and Huberman models. The result of Islamic story method implementation in instilling religious moral in MIS Nurul Islam Seresam found that the moral changes of students occurring in school environment such as students often start to perform prayers at school, students begin to interact well with teachers and peers, students begin to show responsible attitude, discipline, and honest attitude. The advantages of the Islamic story method, the story can activate and awaken the students, emotionally directing the students well.
\end{abstract}

Keywords: Story methods, instill religious morality, students (MIS).

\section{Pendahuluan}

Seperti yang kita ketahui tujuan pendidikan adalah usaha sadar dan terencana untuk mewujudkan suasana belajar dan proses pembelajaran agar siswa secara aktif mengembangkan dirinya untuk memiliki kekuatan spiritual keagamaan, pengendalian diri, kepribadian, kecerdasan, akhlak mulia, serta keterampilan yang diperlukan dirinya, masyarakat, bangsa dan negara. Pengembangan moral di sekolah merupakan 
pembentukan perilaku anak melalui pembiasaan yang terwujud dalam keadaan seharihari, hal tersebut untuk mempersiapkan sedini mungkin dalam mengembangkan sikap dan perilaku yang dilandasi moral pancasila. Pada siswa, nilai moral akan terlihat dari mampu tidaknya seorang siswa yang mampu membedakan antara yang baik dan yang buruk, jujur, rapi dalam bertindak dan berpakaian sopan, ramah, tidak berkata kasar, menghormati guru, memiliki tanggung jawab, sopan santun, menghargai teman dan menjaga kebersihan lingkungan.

Menurut (Licona, 2015) hendaknya sekolah bisa menerapkan kepada siswa pendidikan moral, yaitu:

(1) Nilai-nilai yang seharusnya dapat diajarkan di sekolah, memiliki tujuan yang bermanfaat secara umum dapat diterima oleh masyarakat yang beragam

(2) Sekolah tidak hanya mengekspos nilai-nilai tersebut kepada para siswa, tetapi juga harus mampu membimbing mereka untuk dapat mengerti, meresapi, dan melakukan nilai-nilai yang berlaku.

Moral bukanlah bawaan lahir dari manusia. Manusia yang baru lahir tidak mengenal moral. Moralitas merupakan sesuatu yang diajarkan atau ditanamkan pada manusia setahap demi setahap, mulai dari dirinya lahir. Dengan demikian, ia akan mampu memahami serta mengaplikasikan moral yang tertanam dalam dirinya tersebut pada lingkungannya. Oleh karena itu, moral atau moralitas merupakan sisi dalam diri manusia yang berkembang seiring dengan perkembangan dirinya. Dengan kata lain, moral atau moralitas berkembang sejalan dengan berkembangnya kemampuan kognitif seseorang. Jika secara logika matematis dapat disimpulkan bahwa semakin bertambahnya umur manusia, maka kemampuan kognitifnya semakin berkembang, sehingga ia dapat berperilaku dengan moralitas yang baik.

Namun, pada tataran realitas, tidak semuanya berkembang sejalan sebagaimana yang diidealkan. Banyak kasus ditemukan di Indonesia, sebagian anak bangsa mengalami kemerosotan moral yang menyangkut persoalan moral, seperti kejujuran, kebenaran, dan keadilan.

Sehingga bangsa ini butuh kembali penanaman nilai-nilai moral keagamaan. Kemerosotan moral yang dilakukan oleh generasi muda, perlu adanya penanganan yang lebih intensif dan urgent, dimana kita sebagai pendidik perlu menanamkan nilai moral sedini mungkin di lingkungan sekolah selain dari lingkungan keluarga. Kemerosotan moral yang dialami anak bangsa, apabila tidak diberikan perhatian khusus akan berakibat buruk bagi generasi mendatang. Oleh karenanya sangat diperlukan adanya pemberian pendidikan moral di sekolah dalam setiap jenjang pendidikan.

Pendidikan moral merupakan salah satu pendekatan yang dianggap sebagai gerakan utama dalam penanaman nilai moral pada siswa di sekolah. Menanamkan pendidikan agama dan moral kepada siswa sejak tingkat dini adalah hal yang sangat penting untuk dilakukan, karena jika siswa hanya memiliki kepintaran saja tanpa akhlak, moral dan etika yang baik, maka kepintaran itu tidak akan bermanfaat kepada kehidupan siswa, yang ada malah memberikan dampak buruk pada perilaku siswa.

Seperti contoh kasus yang terjadi disalah satu daerah yang ada di Indonesia, seorang guru kesenian di SMAN 1 Torju, Kabupaten Sampang, Jawa Timur, yang bernama Ahmad Budi Cahyono alias (Guru Budi), tewas digebuk (pukul) siswanya. Peristiwa sadis dan tragis ini semakin memilukan ketika diketahui, ternyata guru Budi 
ini, masih berstatus sebagai tenaga pengajar honorer alias guru tidak tetap (Kuswandi, 2018).

Pada kasus lainnya dimuat di halaman tribun Jateng Garut (edy, 2018), yang terjadi bertepatan hari anak nasional. Warga kabupaten Garut dihebohkan oleh kasus pembunuhan terhadap anak-anak yang dilakukan juga oleh anak-anak. Seorang siswa sekolah dasar (SD), di kecamatan Cikajang, tewas pada Minggu (22/7/2018), setelah ditusuk teman sebangkunya sehari sebelumnya, penyebab kematian korban karena alasan sepele. Korban berinisial FDL (12), dituduh oleh terduga pelaku berinisial MH (12), menyembunyikan salah satu buku pelajaran yang hilang. Mirisnya peristiwa itu terjadi bertepatan dihari anak-anak nasional dan Kabupaten Garut baru dianugerahi penghargaan kabupaten layak anak oleh Menteri Pemberdayaan Perempuan dan Perlindungan Anak (PPPA).

Selain itu kasus krisis moral juga terjadi kembali, dimana seorang guru yang menegur siswanya sedang merokok di kelas, tetapi siswa tersebut tidak terima dan malah melawan, bahkan mencekik gurunya. Kasus ini juga merupakan kasus dimana siswa tidak memiliki moral dan bertindak hanya berdasarkan keinginannya atau egonya sendiri. Tindakan siswa ini sangat tidak bermoral, siswa ini tidak hanya melawan orang yang lebih tua darinya, tetapi ia juga tidak mau menerima kesalahan yang dia perbuat (Pangwijaya, 2019).

Berdasarkan hasil survei awal pada tanggal 24 februari 2020, yang peneliti lakukan disalah satu sekolah di Indragiri Hulu, peneliti menemukan siswa yang tidak menaati peraturan sekolah, seperti adanya siswa yang masih di kantin pada jam pelajaran dengan alasan ke toilet, adanya siswa yang selalu berkata-kata kasar, kotor, siswa yang melawan guru waktu di suruh melaksanakan sholat, dan ribut ketika guru menjelaskan pembelajaran, bahkan ada juga siswa yang berkelahi, selanjutnya juga ditemukan siswa yang berbohong kepada guru dan orang tua dengan alasan pergi sholat dan mengaji, akan tetapi malah merokok serta adanya siswa yang berani meminta secara paksa uang temannya dan banyak kasus lainnya yang telah terjadi. Beberapa kasus lainnya yang bila dikaji dapat merusak moral keagamaan siswa itu sendiri.

Terkait dengan kasus amoral siswa di atas pada dasarnya pembentukan moral anak secara mendasar tergantung kepada orang-orang yang membentuknya dan situasi lingkungan yang mendukungnya. Anak yang hidup pada kondisi lingkungan yang membentuk kepribadian baik tentu akan menjadi baik, selama belum terkontaminasi dengan hal-hal yang buruk, begitu juga sebaliknya ketika anak hidup pada kondisi lingkungan yang buruk tentu akan terbentuk kepribadian yang buruk selama belum terkontaminasi dengan hal-hal yang baik yang bisa mengubah, selain orang tua, sekolah tentunya juga merupakan solusi menanamkan moral yang baik untuk siswa.

Pendidikan moral di sekolah hendaknya diterapkan sejalan dengan pemikiran pendidikan dasar moral, menurut John Mahoney dalam (Ruslan, Elly, \& Aini, 2016) mengatakan bahwa memasukkan seluruh kegiatan sekolah termasuk kegiatan ektra kurikulumnya dalam kerangka pendidikan nilai moral. Kegiatan di dalam dan di luar kelas, diupayakan memuat nilai-nilai moral yang berguna bagi pembentukan kepribadian siswa sebagai bekal hidup bermasyarakat masa kini dan masa datang. Pendeknya seluruh kegiatan di sekolah yang menjadi tanggung jawab sekolah diupayakan memuat pendidikan nilai moral. Ada banyak metode yang bisa 
menanamkan moral yang baik pada siswa, salah satunya dengan metode cerita. Seperti pada penelitian yang dilakukan (putri, 2017) yang menggunakan metode cerita untuk mengembangkan nilai moral anak, dengan hasil penelitiannya lebih efektif penggunaan metode cerita untuk mengembangkan nilai menghargai teman, sopan santun, dan tanggung jawab, dan menyarankan kepada guru sebaiknya menggunakan teknik bercerita yang sesuai dengan tahap perkembangan anak, baik dari bahasa, media dan langkah-langkah pelaksanaannya.

Senada dengan penelitian yang dilakukan oleh (kubra, 2019) tentang pengaruh penerapan metode bercerita terhadap penanaman nilai-nilai moral pada anak usia dini di taman kanak-kanak negeri pertiwi letta kabupaten bantaeng. Subjek penelitian adalah guru dan 15 orang anak di kanak-kanak negeri pertiwi letta kabupaten Bantaeng, ditinjau dari hasil prestest dan posttest yang dilakukan terdapat peningkatan penialian terhadap anak setelah perlakuan, anak mampu memahami dan menerapkan nilai-nilai moral tersebut dengan baik pemberian metode cerita.

Kecerdasan moral menurut (Borba, 2008) adalah kemampuan memahami hal yang benar dan yang salah, artinya memiliki keyakinan etika yang kuat dan bertindak berdasarkan keyakinan tersebut, sehingga orang bersikap benar dan hormat. Nilainilai moral dalam masyarakat bersumber pada nilai agama yang diyakini oleh suatu kelompok. Nilai-nilai moral yang bersumber dari agama memberikan pengertian yang lebih jelas mengenai perilaku yang seharusnya dilakukan dan tidak dilakukan. Nilai ini bersifat universal sehingga dapat diterima oleh kelompok sosial di manapun kelompok itu berada. Sebagai filter, pendidikan agama yang sifatnya praktis sangat dibutuhkan. Bobot pendidikan agama bukan hanya terletak pada unsur kognitifnya tetapi lebih banyak menyentuh pada unsur afektif (perasaan) dan motorik (perilaku) sehingga nilai aplikasinya bisa langsung dirasakan oleh anak. Sebagian ahli psikologi menyatakan bahwa sebagian perilaku moral dan kebiasaan seseorang dibimbing oleh keyakinan agama. Pengaruh agama dapat terjadi dalam bentuk positif yaitu membentuk kesehatan mental dan pertumbuhan seseorang. Pengajaran pendidikan agama merupakan salah satu upaya membentuk kualitas internal sebagai pendorong manusia berperilaku moral. Pendidikan moral menurut (Ibda, 2012) adalah kesadaran untuk membantu siswa melalui ilmu pengetahuan, keterampilan, sikap, dan nilai yang memberikan kontribusi pada kepuasan individu dan kehidupan sosial.

Definisi ini menggambarkan bahwa pendidikan moral bermuara pada dua tujuan. Pertama, membantu generasi muda dalam memperoleh ilmu pengetahuan, keterampilan, sikap, dan nilai untuk kepuasaan hidup yang lebih baik. Kedua, membantu individu mencapai kehidupan sosial sekaligus memberikan kontribusi kepada terciptanya masyarakat yang lebih baik didasarkan pada kepedulian dan perasaan kasih kepada umat manusia dan makhluk hidup serta tidak mengganggu hak-hak orang lain untuk memenuhi nilai legitimasi dirinya.

Konsep moral yang dijelaskan oleh (Ali, 2012) merupakan standar baik atau buruk setiap individu oleh nilai-nilai sosial budaya, dimana individu sebagai anggota sosial. Moralitas merupakan aspek kepribadian yang diperlukan seseorang dalam kaitannya dengan kehidupan sosial secara harmonis, adil, dan seimbang. Perilaku moral diperlukan terwujudnya kehidupan yang damai penuh keteraturan, ketertiban dan keharmonisan, adapun contoh sederhana perilaku moral yang kadang terlupakan di masyarakat yakni sebagai berikut:

1. Membuang sampah tepat pada tempatnya. 
2. Membungkukkan badan ketika melewati orang yang lebih tua.

3. Mengucapkan terima kasih ketika mendapat pemberian dari seseorang.

4. Menyelesaikan tugas tepat pada waktunya.

5. Menyantuni anak yatim dan piatu di panti asuhan.

6. Memberikan pemberlajaran untuk anak-anak jalanan.

7. Menunaikan ibadah tepat pada waktunya.

8. Menghargai pendapat orang lain saat rapat sedang berlangsung.

9. Mencium tangan orang tua saat hendak keluar rumah.

10. Memberikan tempat duduk saat di kendaraan umum untuk orang tua maupun ibu hamil yang tidak mendapat tempat duduk.

Adapun indikator moral yang baik menurut (Subur, 2015) pada Tuhan, pada diri sendiri siswa, dan pada teman sebaya, yang termuat pada tabel berikut ini:

Tabel. 1 Indakator Nilai Moral

\begin{tabular}{ccl}
\hline No & Nilai moral & \multicolumn{1}{c}{ Indikator moral } \\
\hline 1 & Pada Tuhan & Melaksanakan sholat \\
2. & Pada diri sendiri & $\begin{array}{l}\text { Istiqomah, sungguh-sunggu, menjaga diri, bertaubat, } \\
\text { ikhlas, ridha, syukur, tidak sombong, tidak tamak, } \\
\text { malu, anti narkoba. }\end{array}$ \\
3. & Pada sesama & $\begin{array}{l}\text { Jujur, adil, pemaaf, dermawan, mengormati orang } \\
\text { tua, bersatu, tidak hasad, rukun/cinta damai. }\end{array}$
\end{tabular}

Moral keagamaan yang berarti nilai atau norma yang dijadikan pegangan bagi seseorang atau kelompok masyarakat yang mengatur tingkah laku dalam kehidupan yang didasarkan pada keyakinan atau agama yang dianut. Senada yang dijelaskan oleh (Lalompo \& Ester, 2017) berpendapat moral keagamaan penting untuk dikembangkan dan diajarkan pada Siswa karena moral keagamaan merupakan faktor hakiki bagi manusia dalam membentuk kepribadian dan karakter utama dalam kehidupan, (Lalompo \& Ester, 2017) juga berpendapat bahwa pengembangan moral keagamaan sangat penting bagi pendidik. Moral keagamaan atau percaya kepada Tuhan sudah ada pada diri manusia sejak lahir, artinya ada potensi tentang dua hal ini yang terdapat dalam diri manusia. Ada ruang dalam diri manusia tentang kedua pokok ini (moral keagamaan) yang harus ditumbuh kembangkan. Penelitian ini adalah penelitian kualitatif, dengan 6 Informan yang terdiri dari Kepala Madrasah, Guru (2 orang) dan Siswa (4 orang).

Salah satu metode yang tepat untuk menanamkan serta mengembangkan nilai moral keagamaan siswa di sekolah bisa dilakukan dengan metode cerita kepada siswa. Metode cerita adalah metode yang digunakan untuk menyampaikan informasi dan pengetahuan secara lisan kepada sekelompok pendengar untuk mencapai tujuan yang diinginkan menurut (Helmiati, 2012). Secara etimologi, (Fadlillah, 2014) menjelaskan metode berasal dari kata method yang artinya sesuatu cara kerja yang sistematis untuk memudahkan pelaksanaan kegiatan dalam mencapai suatu tujuan.

Metode pembelajaran dapat pula diartikan sebagai suatu cara yang sistematis untuk melakukan aktivitas atau kegiatan pembelajaran yang tujuannya mempermudah dalam mencapai tujuan pembelajaran yang diinginkan, dalam pembahasan ini metode pembelajaran dilakukan dengan cerita. Senada yang dijelaskan oleh (Majid, 20o8) Cerita adalah salah satu bentuk sastra yang bisa dibaca atau hanya didengar oleh orang yang tidak membaca. (Tafsir, 2003) mengatakan bahwa cerita merupakan metode amat penting, alasannya: 
a. Kisah selalu memikat karena mengundang pembaca atau pendengar untuk mengikuti peristiwanya.

b. Kisah Qur'ani dan nabawi dapat menyentuh hati manusia.

c. Kisah Qur'ani mendidik perasaan keimanan.

Secara bahasa, cerita adalah rangkaian peristiwa yang disampaikan kepada orang lain baik dari suatu kejadian nyata maupun tidak nyata. Kata cerita satu makna dengan kisah, stori, riwayat berita atau kabar. Kata dongeng berarti cerita rekaan atau tidak nyata, seperti fabel dan legenda. Jadi dongeng adalah cerita, tetapi cerita belum tentu dogeng (Bimo, 2013). Cerita merupakan salah satu bentuk sastra yang memiliki keindahan kenikmatan tersendiri. Hal ini dimaksudkan bahwa sesuatu yang nyata maupun tidak nyata disampaikan kepada orang lain dapat disebut sebagai cerita, tetapi sebuah dongeng hanyalah cerita yang disampaikan berupa kejadian tidak nyata.

Metode bercerita berarti penyampaian cerita dengan cara beruntun, yang membedakan antara bercerita dengan metode penyampaian cerita lain adalah lebih menonjolkan aspek teknik penceritaan. Tegasnya metode bercerita lebih menonjolkan penuturan lisan materi cerita dibandingkan aspek teknis lainnya (Bimo, 2013: 19). Senada yang diungkapkan oleh (Nata, 2008), bahwa metode bercerita adalah suatu metode yang mempunyai daya tarik yang menyentuh perasaan sipendengarnya dalam hal ini adalah siswa.

Sudah sifat alamiah manusia untuk menyenangi cerita yang pengaruhnya besar terhadap perasaan manusia itu sendiri. Oleh karenanya metode cerita, dijadikan sebagai salah satu teknik pendidikan dalam proses pembelajaran. Dunia kehidupan Siswa dapat berkaitan dengan lingkungan keluarga, sekolah, dan luar sekolah. Kegiatan bercerita harus diusahakan menjadi pengalaman bagi siswa ditingkat dasar yang bersifat unik dan menarik yang menggetarkan perasaan siswa dan memotivasi siswa untuk mengikuti cerita sampai tuntas.

Penggunaan metode bercerita sangat mempengaruhi peningkatan perkembangan nilai agama dan moral siswa. Dengan menggunakan metode bercerita ini maka siswa akan mengetahui tentang keagamaan dan moral dari sifat suatu tokoh dalam cerita dan tema cerita yang disampaikan. Pengertian di atas, peneliti sependapat dengan penjelasan tersebut, bahwa metode bercerita merupakan menuturkan atau menyampaikan cerita secara lisan kepada siswa sehingga dengan cerita tersebut dapat disampaikan pesan-pesan yang baik dengan metode bercerita dapat mengundang perhatian siswa pada proses pembelajaran, yang terhubung langsung menyentuh pada perasaaan siswa. Peneliti beranggapan bahwa metode cerita bukan hanya menyampaikan informasi dengan lisan kepada si-pendengar tetapi juga dengan peragaan atau prakter agar cerita yang disampaikan menarik.

Terkait pembahasan di atas, ada hal yang menarik untuk dibahas dalam penelitian ini, yakni bagaimana hasil implementasi metode cerita terhadap perkembangan Moral Keagamaan siswa di MI Nurul Islam Desa Seresam dan kelebihan serta kekurangan dari metode ini. Proses Penelitian ini menggunakan metode kulitatif, dengan pendekatan tindakan kelas studi kasus, yakni dimana peneliti memecahkan masalah praktis yang dihadapi oleh guru itu sendiri dalam proses pembelajaran di sekolahnya, dengan menggunakan penerapan langkah model Kurt lewin yang dijelaskan oleh (Sanjaya, 2011) yaitu adanya perencanaan, tindakan, observasi, dan refleksi dimana proses yang terjadi dalam suatu lingkaran yang terus menerus. Seperti gambar berikut ini: 


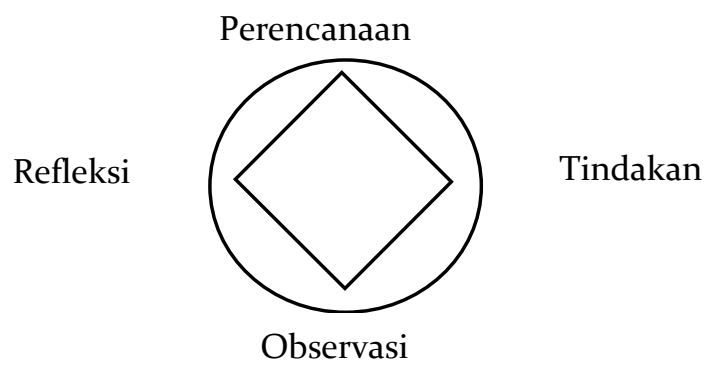

\section{Gambar I. Model PTK Kurt Lewin}

Adapun yang menjadi Pedoman observasi dan wawancara dalam penelitian ini adalah sebagai berikut:

Tabel : 2 Pedoman Observasi Guru dan Siswa

\begin{tabular}{ccc}
\hline No & Pedoman & Prediksi \\
& & Moral \\
& keagamaan & Sikap-sikap moral yang \\
& pada Siswa & terjadi seperti \\
& & mencuri/merampas uang \\
& milik teman sebayanya, \\
& melawan kepada orang \\
& & tua/guru, berkata \\
& & kotor/kasar, berkelahi \\
& & sesama teman, berkata \\
& & tidak jujur, dan tidak \\
& & memiliki sopan santun
\end{tabular}

\begin{tabular}{cc} 
& \multicolumn{2}{c}{ Indikator } \\
\hline Guru & Siswa \\
a. Usaha yang & a. Latar belakang yang \\
dilakukan guru & menyebabkan \\
untuk mengatasi & kurangnya sikap moral \\
kenakalan pada & pada Siswa. \\
Siswa. & b.Aktifitas yang \\
b. Kebijakan/peratura & dilakukan Siswa \\
n yang dibuat oleh & kepada Tuhan \\
sekolah. & (melaksSiswaan \\
& sholat), kepada diri \\
& sendiri (jujur, disiplin, \\
& kreatif, rasa ingin tahu, \\
& tanggung jawab) dan \\
& pada sesama (jujur, \\
& adil, menghormati \\
& orang tua, Pemaaf).
\end{tabular}

2. Metode cerita Langkah-langkah

Implementasi metode cerita antara lain: bercerita dengan alat peraga, bercerita dengan buku, dan bercerita dengan gambar. a. Melihat sejak kapan metode cerita digunakan.

b. Teknik dalam penggunaan metode cerita a. Hasil Implementasi metode cerita Pada

Moral Siswa

b. Kelemahan dan keunggulan metode cerita.

Tabel. 3 Pedoman Wawancara Guru dan Siswa

\begin{tabular}{cccc}
\hline No Pedoman & Prediksi & \multicolumn{2}{c}{ Pedoman Wawancara } \\
\cline { 3 - 4 } & & Guru & Siswa \\
\cline { 3 - 4 } Moral & Sikap-sikap moral & a. Usaha yang dilakukan & \\
& yang terjadi seperti & guru untuk mengatasi & Aktifitas yang \\
mencuri/merampas & moral negatif pada & dilakukan Siswa \\
& uang milik teman & kepada Tuhan \\
& sebayanya, melawan & b. Kebijakan/peraturan & (melaksSiswaan \\
kepada orang & yang dibuat oleh & sholat), kepada diri \\
& tua/guru, berkata & sekolah & sendiri (jujur, \\
& kotor/kasar, berkelahi & c. Faktor penyebab & disiplin, kreatif, rasa \\
& sesama teman, & terjadinya moral & ingin tahu, \\
& berkata tidak jujur, & negatif pada Siswa & tanggung jawab) \\
dan tidak memiliki & & dan pada sesama \\
& sopan santun & & (jujur, adil, \\
& & & menghormati orang
\end{tabular}


tua, Pemaaf).

$\begin{array}{cccc}\text { 2. Metode cerita } & \text { Langkah-langkah } & \text { a. Penerapan yang } & \text { Kelemahan dan } \\ & \text { awal terhadap metode } & \text { dilakukan guru untuk } & \text { keunggulan metode } \\ \text { cerita antara lain: } & \text { mengatasi sikap Siswa- } & \text { cerita } \\ \text { bercerita dengan alat } & \text { Siswa yang tidak taat } & \\ \text { peraga, bercerita } & \text { peraturan sekolah } & \\ \text { dengan buku, dan } & \text { b. Teknik dalam } & \\ \text { bercerita dengan } & \text { penggunaan metode } & \\ \text { gambar. } & \text { cerita }\end{array}$

\section{Hasil}

Hasil penelitian ini membahas dua bagian yang pertama, melihat hasil implementasi metode cerita, dalam menanamkan moral keagamaan kepada siswa di MIS Nurul Islam Seresam dengan pendekatan tindakan kelas berdasarkan Model Kurt Lewin. Kedua melihat bagaimana kelebihan dan kekurangan implementasi metode ini yang akan dijabarkan di bawah ini:

a. Implementasi metode cerita, dalam menanamkan moral keagamaan kepada siswa di MIS Nurul Islam Seresam

Pada tahapan pertama peneliti menerapkan dua langkah, dalam perencanaan ini peneliti melakukan persiapan pelaksanaan metode cerita, dengan beberapa tahapan sebagai berikut:

a). Perencanaan tahapan pertama

1) Memilih dan memilah materi cerita

Sebelum memulai cerita, peneliti terlebih dahulu memilih cerita yang berhubungan dengan sebuah materi pembelajaran sehingga cerita yang disampaikan dapat membuat siswa paham dan mengerti. Peneliti memilih cerita yang berhubungan dengan materi pembelajaran, seperti cerita Tsalabah Bin Hathib (Ketika Miskin Rajin Sholat, Setelah Kaya Enggan Sholat), yang dapat dihubungkan pada pelajaran fiqih.

2) Pengelolaan kelas dan tempat untuk bercerita

Bukan hanya memilih sebuah cerita yang menarik untuk didengar tapi juga membuat suasana kelas menjadi nyaman dan tentram sehingga apa yang disampaikan lewat cerita membuat siswa mudah memahami. Peneliti melakukan proses pembelajaran bukan hanya di dalam ruangan namun juga di luar kelas, sehingga proses pembelajaran yang disampaikan lewat cerita dapat dinikmati dan disukai siswa. Peneliti juga memberikan praktek lewat cerita seperti apa sikap yang baik dicontoh dan harus dimiliki, seperti bersikap jujur, rajin menolong sesama, berbakti kepada orang tua dan guru dan sikap mulia lainnya.

3) Strategi penyampaian

Peneliti melakukan strategi penyampaian dengan cara notasi nada yang bervariasi sehingga membuat siswa happy, ketakutan, tertawa, menangis dan bahkan terharu mendengarkan cerita tersebut. Peneliti juga menggunakan strategi demontrasi yang dipraktekan siswa sehingga dengan mudah mereka dapat pahami apa yang disampaikan, dan dapat terapkan pada kehidupan sehari-hari dengan baik. 
b). Tindakan tahap pertama

Banyak tindakan yang peneliti lakukan lainnya, seperti peneliti memberikan Reward kepada siswa berupa pujian, makanan dan minuman, bagi siswa yang bisa memceritakan ulang cerita yang peneliti ceritakan bahkan memberikan pujian kepada siswa yang berani tampil untuk bercerita. Dengan tindakan ini peneliti berharap siswa berani dengan tanggung jawab yang diberikan sehingga sikap moral berani bertanggung jawab dapat tertanam dengan baik pada diri setiap individunya.

c). Observasi tahap pertama

Beberapa persiapaan yang peneliti lakukan ternyata secara perlahan menemukan hasil yang cukup baik mengenai sikap siswa, yang biasanya suka mencuri uang temannya, kini siswa tersebut sudah paham bahwa mencuri adalah perbuatan yang tidak baik, dan dapat merusak sikap moral, bahkan sikap seperti itu dijauhi banyak teman. Hal ini juga dibuktikan dengan hasil wawancara 4 orang siswa, sebagai berikut:

1). Bagaimana belajar dengan menggunakan metode cerita?

Berdasarkan hasil wawancara dari keempat siswa peneliti menyimpulkan bahwa belajar dengan metode cerita awalnya sulit memahami dari pesan moral atau materi yang diajarkan, tetapi secara perlahan-lahan mulai dapat memahami pesan moral yang disampaikan dengan metode cerita.

2) Apakah pesan moral yang disampaikan melalui metode cerita mudah diterapkan dikehidupan sehari-hari?

Berdasarkan hasil wawancara dari keempat siswa peneliti menyimpulkan bahwa mengalami sedikit kesulitan, tapi kerena menjadi kebiasaan menjadi hal mudah untuk dilaksanakan dengan baik oleh siswa, karena itu semua membuat diri menjadi lebih baik.

3). Adakah kesulitan yang dialami dengan metode cerita?

Berdasarkan hasil wawancara dari keempat siswa peneliti menyimpulkan ada, salah satunya bosan, jenuh, bahkan sulit memahami pembelajaran yang ada pada cerita tersebut, tetapi secara perlahan semua itu bisa diatasi dengan gaya cerita yang lebih bervariasi.

d). Refleksi tahap pertama

Analisi peneliti tentang hasil observasi diatas bahwa moral negatif terjadi bukan hanya terjadi di sekolah saja, namun di luar sekolah juga terjadi, penyebab adalah faktor lingkungan yang sangat berpengaruh seperti faktor lingkungan keluarga yang kurangnya perhatian dari orang tua yang terlalu sibuk bekerja, dan faktor teknologi seperti game online, tontonan situs porno dan lainnya. Upaya untuk mengubah moral negatif yang terjadi sudah dilakukan oleh pihak sekolah seperti nasehat, hukuman, dan terakhir pemanggilan orang tua, tetapi berdasarkan hasil observasi peneliti ini semua belum maksimal, karena kurangnya sikap tegas yang diberikan oleh pihak sekolah dan yayasan. Penetapan kebijakan lain seharusnya diracanangkan oleh pihak sekolah 
berupa metode pembelajaran yang bisa mengubah moral siswa agar menjadi lebih baik.

Hasil dari penerapan ini semua, peneliti menemukan perubahanperubahan moral siswa yang terjadi dilingkungan sekolah seperti:

1) Siswa mulai sering melaksanakan sholat di sekolah.

2) Siswa mulai berinterasi dengan baik kepada guru dan teman sebayanya

3) Siswa mulai berbicara sopan kepada guru

4) Siswa mulai menunjukan sikap bertanggung jawab terhadap kelasnya, seperti membersihkan kelas, mengerjakan tugas sekolah

5) Mulai menunjukan kedisiplinan yang baik seperti datang tepat waktu.

6) Siswa mulai menunjukakan sikap jujur.

7) Siswa mulai tidak menunjukan sikap untuk menggambar porno dan menonton flim porno.

Adapun tahapan selanjutnya pada pelaksanaan penelitian tindakan kelas dalam penelitian ini, penjabarannya sebagai berikut:

a) Perencanan tahap kedua

Dari perencanaan tahap pertama yang sudah peneliti lakukan, peneliti akan melakukan kembali diperencanaan awal metode cerita dalam proses pembelajaran untuk meningkatkan sikap moral positif pada siswa, namun kali ini peneliti lebih banyak mempraktekkan sebuah metode cerita berupa cerita Islami kepada siswa, agar siswa lebih dalam untuk tingkat pemahaman, dan peneliti juga mengkaitkan praktek yang dilakukan dengan kehidupan sehari-hari sehingga secara tidak sadar mereka sudah mampu melakukannya dengan baik.

b) Tindakan tahap kedua

Dengan perencanaan yang sudah peneliti tetapkan lebih memperbanyak cerita Islami dan mempraktekannya sesuai kehidupan sehari-hari kepada siswa, peneliti juga melakukan tindakan agar siswa dapat memahaminya dengan baik dan diaplikasikan dalam kehidupan sehari-hari dengan baik. Tindakan yang peneliti lakukan berupa praktek dari cerita Islami tersebut seperti cerita orang yang sabar, siswa mempraktekan sikap orang yang sabar ketika diejek temannya, bukannya hanya itu juga, siswa mempraktekan bagaimana menasehati teman yang sedang mencuri, bahwa mencuri adalah perbuatan yang tidak baik dan akan dijauhi banyak teman. Setelah praktek yang dilakukan peneliti meminta siswa untuk diskusi tentang sikap moral negatif yang tidak boleh dilakukan, dan kemudian mempraktekan perbuatan yang baik dilakukan dalam kehidupan sehari-hari.

c) Observasi tahap kedua

Ditahapan kedua observasi ini, peneliti banyak menemukan perubahan sikap moral yang lebih baik pada siswa, dari sikap siswa yang suka mencuri, menjahili teman, pelit sama teman, meminta paksa uang kepada teman, saling buat gang sesama teman, ngejek teman, menggambar gambar porno, melawan guru, suka berantam, suka nonton flim porno, suka merokok, bolos belajar melawati jendela, dan hal 
lainnya kini siswa yang sering melakukan moral negatif mulai tampak terlihat baik.

d) Refleksi tahap kedua

Hasil observasi di atas terdapat hasil yang baik, kini siswa-siswi yang berperilaku tidak baik secara perlahan mulai terlihat sangat baik. Nilai dari hasil belajar siswa mulai meningkat, untuk progam selanjutnya peneliti berharap besar kepada pihak sekolah untuk lebih meningktkan kedisiplinan guru dan siswa datang lebih tepat waktu. Guru lebih banyak memperhatikan sikap siswa baik di dalam kelas ataupun di luar kelas karena lingkupan sekolah ada tanggung jawab guru, pihak sekolah juga harus memberikan wewenang pelatihan kepada guru agar lebih profesional dalam mengajar sehingga apa yang diajarkan kepada siswa dapat dimengerti dengan baik sehingga siswa dapat mempraktekannya di luar sekolah dengan baik pula.

Hasil penelitian di atas senada dengan penelitian yang dilakukan oleh (safitri, 2019) tentang penerapan metode cerita dalam menanamkan moral siswa sekolah dasar, dihasilkan bahwa penggunaan metode bercerita dapat meningkatkan perkembangan nilai agama dan moral siswa, sehingga siswa lebih senang, antusias, dan mudah memahami. Dengan persentase proses siklus penelitian tindakan kelas sebagai berikut:

1. Hasil siklus 1, belum ada perkembangan pesat, akan tetapi ada 10 siswa dengan (41,67\%), dengan kategori mulai berkembang. 11 siswa $(45,83 \%)$, dengan kategori berkembang sesuai harapan. Pada siklus I ini terdapat beberapa anak yang kurang memperhatikan, hilangnya fokus dalam mengikuti kegiatan, kurang minat dan lain sebagainya.

2. Pada siklus ke II, permasalahan tersebut sudah mulai berkurang dan hasil yang dicapai masuk dalam kategori berkembang sesuai harapan. Pada siklus II mengalami peningkatan pada kategori berkembang sangat baik sebesar $(66,66 \%)$.

b. Kelebihan dan kekurangan metode cerita terhadap perkembangan moral keagamaan siswa di MI nurul Islam desa Seresam.

Berbicara dari kelebihan dan kekurang metode cerita semua itu tergantung bagaimana seorang guru menyampaikan cerita dengan baik atau semenarik mungkin, agar cerita yang disampaikan membuat siswa senang dan proses pembelajaran berjalan dengan baik bahkan membuat siswa paham. Sesuai yang peneliti lakukan. Metode cerita yang dipakai beragam tindakan dan metode, seperti halnya seorang siswa mendemontrasikan sebuah cerita tersebut, seorang siswa menceritakan kembali cerita tersebut, dan lainnya.

Tidak jauh hasil pengamatan yang peneliti dengan wawacara oleh guru mengenai penggunaan metode cerita dalam proses pembelajaran. Sesuai jawaban dari beberapa guru mengenai hal tersebut dapat disimpulkan bahwa ketika menggunakan metode cerita dalam proses belajar tidak semudah yang dilihat, harus mempunyai teknik bercerita yang baik dan mempunya ragam cerita yang banyak, sehingga cerita yang disampaikan sesuai pembeljaran yang berlangsung yang membuat siswa mudah paham dari pesan moral yang disampaikan dicerita tersebut.

Berdasarkan hasil observasi peneliti yang menjadi kekurangan dari metode cerita itu sendiri adalah bosan atau jenuh, sering tidak selaras antar cerita dan 
pembelajaran, namun disisi lain metode cerita memiliki sebuah kelebihan diantaranya membuat siswa senang dari cerita tersebut, bisa mengontrol emosi, bahkan bisa memikat suasana yang nyaman dari cerita tersebut, adapun penjabarannya terlihat di bawah ini:

a. Hasil kelebihan implentasi metode bercerita

a) Kisah dapat mengaktifkan dan membangkitkan semangat siswa. Terlihat saat implikasi metode cerita pada siswa, siswa senantiasa memahami makna dan sehingga siswa termotivasi oleh tokoh dan topik cerita tersebut.

b) Mengarahkan semua emosi sehingga menyatu pada satu kesimpulan yang terjadi pada akhir cerita.

c) Siswa mampu mengembangkan imajinasi dan fantasi anak terkait cerita yang disampaikan.

d) Cerita mampu memikat siswa, karena mengundang siswa untuk mengikuti peristiwanya dan merenungkan maknanya.

e) Terlihat mempengaruhi emosi siswa, seperti takut, perasaan diawasi, rela, senang, sungkan, atau benci sehingga bergelora dalam lipatan cerita.

b. Hasil kekurangan implentasi metode bercerita metode bercerita

a) Terlihat pemahaman siswa menjadi sulit ketika kisah itu telah terakumulasi oleh masalah lain.

b) Siswa mulai jenuh, jika metode yang berikan tidak menarik dan monoton atau pada jam-jam pelajaran yang mempengaruhi kondusifnya lingkungan belajar.

c) Pada pelaksanaanya oleh guru, terkdang terjadi ketidakselarasan antara isi cerita dengan konteks yang dimaksud sehingga pencapaian tujuan sulit diwujudkan oleh siswa.

Hasil penemuan di atas sesuai dengan tujuan metode cetita seperti yang diungkapkan oleh (Majid, 2008) sebagai berikut:

a) Menghibur dan menyenangkan siswa dengan bercerita yang baik

b) Membantu pengetahuan siswa secara umum

c) Mengembangkan imajinasi

d) Mendidik akhlak

e) Mengasah rasa.

Selain itu hasil penelitian yang penelti temukan, juga tidak jauh berbeda dengan penjelasan (Madyawati, 2016), terdapat beberapa manfaat positif metode bercerita yaitu sebagai berikut:

1. Membantu pembentukan pribadi dan moral siswa. Cerita sangat efektif membantu pribadi dan moral siswa. Melalui cerita, siswa dapat memahami nilai baik dan buruk yang berlaku di masyarakat.

2. Menyalurkan kebutuhan imajinasi dan fantasi. Cerita dapat dijadikan sebagai media menyalurkan imajinasi dan fantasi siswa. Pada saat menyimak cerita. Imajinasi yang dibangun siswa saat menyimak cerita memberikan pengaruh positif terhadap kemampuan siswa dalam menyelesaikan masalah secara kreatif.

3. Memacu kemampuan verbal siswa. Cerita dapat memacu kecerdasan linguistik siswa. Cerita mendorong siswa bukan saja senang menyimak cerita 
tetapi juga senang bercerita atau berbicara. Siswa belajar tata cara berdialog dan bernarasi.

4. Kegiatan bercerita memberikan sejumlah pengetahuan sosial nilai-nilai moral keagamaan. Bercerita memberikan nilai-nilai sosial pada siswa, seperti patuh pada perintah orang tua, mengalah pada adik, dan selalu bersikap jujur. Selain pengetahuan sosial kegiatan bercerita merupakan alat pendidikan budi pekerti yang paling mudah dicerna siswa di samping teladan yang dilihat siswa tiap hari.

5. Kegiatan bercerita memberikan pengalaman belajar untuk melatih pendengarannya. Dalam kegiatan bercerita siswa akan menyampaikan berbagai macam ungkapan, berbagai perasaan sesuai dengan apa yang dialami, dirasakan, dilihat, dididengar, dengan melatih pendengarannya akan menambah kosa kata yang dimiliki siswa.

6. Memberikan pengalaman belajar dengan menggunakan metode bercerita memungkinkan siswa mengembangkan kemampuan kognitif, afektif, dan psikomotor.

7. Memberikan pengalaman belajar yang unik dan menarik, serta dapat mengatakan perasaan, membangkitkan semangat dan menimbulkan keasyikan tersendiri. Kegiatan bercerita memberikan daya tarik bagi siswa sehingga akan menimbulkan semangat dan keasyikan dalam bercerita.

Hasil penelitian di atas juga selaras dengan penelitian yang dilakukan oleh (Putri, Penggunaan Metode Cerita Untuk Mengembangkan Nilai Moral Anak TK/SD, 2017), bahwa manfaat metode bercerita mampu mengubah etika anak-anak (siswa), karena sebuah cerita mampu menarik anak-anak (siswa) untuk menyukai dan memperhatikan, serta merekam peristiwa dan imajinasi yang ada dalam cerita. Selain itu bercerita dapat pula memberikan pengalaman dan pembelajaran moral melalui sikap-sikap dari tokoh yang ada dalam cerita, memberikan pembelajaran dan semangat baru bagi anak-anak (siswa), serta untuk mengetahui adanya peranan metode bercerita dalam mengembangkan nilai-nilai moral pada anak tingkat taman kanak-kanak dan sekolah dasar.

\section{DISKUSI}

Moral merupakan ajaran tentang baik atau buruk perbuatan dan akhlak yang dimiliki oleh seseorang. Memiliki moral yang baik sangat-sangat dibutuhkan, terlebih lagi harus dilengkapi dengan moral keagamaan yang baik dan benar, proses pemberian pengajaran moral keagamaan ini hendaknya sejak dini kepada anak (siswa). Beberapa faktor yang dapat mempengaruhi nilai moral anak (siswa) yakni:

1. Faktor lingkungan keluarga

Orang tua wajib menerapkan moral yang baik terhadap anak, karena anak juga pasti bersosialisasi dan bermasyarakat terhadap teman atau terhadap orang yang lebih tua di sekelilingnya. Jadi, anak harus mempunyai moral yang baik, supaya memiliki sopan santun dimanapun tempatnya. Jika orangtua mengajarkan moral kepada anak melalui kebiasaan sehari-harinya. Pasti dimanapun tempatnya anak secara langsung menerapkan akhlak atau moral yang baik. Jika sebalikya, orang tua tidak mengajarkan moral yang baik untuk anak pasti anak berbuat seenaknya saja, anak tidak sopan santun, anak tidak menghormati jika ada orang yang lebih tua. Seperti kasus yang telah 
dijelaskan di atas, banyak anak yang kurang mempunyai etika terhadap orang dewasa. disini peran lingkungan keluarga, orangtua harus saling mendampingi anak supaya mempunyai moral yang baik supaya bisa di terima di masyarakat dan juga baik di masyarakat.

2. Faktor lingkungan sekolah

Setelah lingkungan keluarga, lingkungan sekolah berperan penting dalam mengembangkan moral anak/siswa, yang bisa diberikan pada proses jam pembelajaran di kelas, maupun di luar jam pembelajaran. Salah satu metode yang bisa diberikan untuk menanamkan dan moral positif kepada siswa dalam proses pembelajaran adalah dengan metode cerita yang diberikan kepada siswa di sekolah.

Memaksimalkan proses pendidikan siswa terutama menstimulus kemampuan siswa melalui metode cerita, secara umum sering dikaitkan dengan kegiatan anak yang dilakukan secara spontan. Penggunaan metode cerita" sangat relevan bagi perkembangan moral dan nilai-nilai agama siswa. Hal ini sejalan pada keterampilan perkembangan sosialisasi siswa.

3. Faktor lingkungan masyarakat

Konteks sosial merupakan hal yang pasti dilalui oleh setiap orang, termasuk bagi siswa dalam tingkat pendidikan sejak dini. Konteks sosial memainkan peran memberikan pengalaman dan pengetahuan yang akan diserap dalam diri siswa. Jika dikaitkan dengan lingkungan pendidikan, maka institusi keluarga menjadi yang pokok, lalu dilanutkan dengan institusi masyarakat yang mana anak/siswa menghabiskan waktu mereka untuk berinteraksi dan bersosialisasi melalui bermain, serta institusi pendidikan yang juga menjadi wadah bagi siswa untuk digembleng secara intelektual maupun kejiwaannya. Peran institusi-institusi ini sangat penting yang akan mendukung proses penanaman dan pembentukan moralitas pada siswa sejak dini (Fitri, 2020).

Berdasarkan penjelasan beberapa para ahli di atas, maka bisa diambil kesimpulan, bahwa perkembangan moralitas pada anak tidak tumbuh sejak lahir, namun terus berkembang seiring didapatkannya berbagai pengalaman dalam rentang usia anak. Perkembangan moral pada anak dipengaruhi oleh dua faktor, yakni faktor internal atau faktor dalam dan faktor eksternal atau luar. Faktor internal atau faktor dalam merupakan faktor kepribadian individu yang telah dikaruniai berbagai potensi, baik akal maupun nurani. Sementara itu, faktor lain yang berpengaruh pada perkembangan moral anak adalah faktor dari luar dirinya atau faktor eksternal. Faktor eksternal atau faktor luar ini terdiri atas konteks atau keadaaan dimana anak tinggal dan konteks sosial atau cara proses interaksinya dengan lingkungan sosial disekitarnya.

Dengan demikian maka orang tua atau pendidik perlu untuk membimbing anak, agar kelak ia memiliki perkembangan moral yang baik serta dapat mengaktualisasikan moralitasnya secara baik, yang jika penerapannya di sekolah bisa dilakukan dengan banyak metode salah satunya dengan metode cerita seperti yang dimpikasikan pada penelitian ini. Pada penelitian lainnya yang dilakukan (Rong \& Noor, 2019) menggunakan metode cerita dalam proses pembelajaran Menulis untuk bahasa Inggris, menunjukkan adanya peningkatan dalam kinerja siswa dan keterampilan siswa, setelah empat proses tahapan dengan menggunakan metode ini. 
Adapun implementasi penelitian ini, dari hasil pengamatan dan wawancara yang telah peneliti lakukan, sebagian besar siswa merasa senang, gembira, tidak bosan mengikuti kegiatan pembelajaran dengan menggunakan metode cerita dan siswa mampu menerapkan moral keagamaan yang baik di sekolah dengan temannya, selain itu juga, saat memainkan tokoh-tokoh dalam cerita, siswa antusias melakukan kegiatan bercerita sangat tinggi, dan siswa merasa ada di dalam kehidupan sebenarnya, seperti yang telah penulis dijelaskan di atas. Implementasi metode cerita dalam menanamkan moral keagamaan siswa, disamping memiliki kelebihan, juga memiliki kekurangan dalam proses implementasinya salah satunya adalah:

1. Daya serap atau daya tangkap siswa berbeda-beda dan masih lemah sehingga sukar memahami tujuan pokok isi cerita.

2. Siswa akan cepat bosan, terutama bila metode cerita yang disampaikan guru tidak menarik atau tidak ada variasinya dengan media lainnya.

3. Jika tidak ada timbal-balik dalam proses pembelajaran dengan metode cerita ini, siswa akan menjadi pasif, karena lebih banyak mendengarkan dan menerima pesan saja

4. Jika metode cerita ini, hanya, satu arah saja, maka perkembangan kreativitas siswa untuk mengutarakan pendapatnya tidak akan berkembang.

Terkait dengan temuan kekurangan di atas, penulis menyarankan kepada pihak penanggung jawab sekolah, baik kepala sekolah, tim kurikulum dan kesiswaan hendaknya lebih aktif memberikn edukasi, pelatihan-pelatihan kepada guru atau tenaga pengajar tentang penerapan metode cerita yang lebih efektif, menarik, kreatif, inovatif dan tepat sasaran, agar proses pengajaran bisa lebih ditingkatkan lagi, sehingga memberikan hasil atau implementasi yang lebih baik terkait moral siswa, dan lebih baik lagi implementasinya sekolah maupun di luar sekolah, serta adanya kerjasasama dan komunikasi yang baik dengan orang tua siswa, agar orang tua melanjutkan pengajaran penanaman moral kepada anaknya di rumah.

\section{KESIMPULAN}

Pendidikan moral keagamaan sangatlah penting diberikan di sekolah kepada siswa, salah satu metode yang menarik yakni dengan menggunakan metode cerita, dari hasil implementasi metode cerita dalam penelitian ini, metode cerita dapat mengaktifkan dan membangkitkan semangat siswa dalam belajar, cerita selalu memikat yang mendengarkannya, karena mengundang pendengar untuk mengikuti peristiwanya dan merenungkan makna cerita yang disampaikan, serta dapat mempengaruhi emosi siswa, seperti takut, perasaan diawasi, rela senang, sungkan, atau benci sehingga bergelora dalam lipatan cerita.

Akan tetapi dengan adanya kelebihan implementasi metode cerita ini, tentunya juga memiliki kekurangan, yang ini menjadi saran penulis dalam penelitian ini, agar pihak sekolah, baik kepala sekolah bersama bagian kurikulum, bagian kesiswaan bisa dengan aktif kembali memberikan edukasi, pelatihan-pelatihan kepada guru di sekolah, terkait metode pengajaran, salah satunya penerapan metode cerita yang lebih kreatif, inovatif lagi, sehingga penerapan metode ini lebih menarik, inovatif dan mampu memberikan hasil yang lebih baik untuk penanaman moral siswa, misalnya ketika guru menggunakan metode bercerita dengan variasi media dan role playing, siswa lebih menarik mau mendengarkan dengan seksama apa yang disampaikan guru, dan guru memberikan kesempatan kepada siswa untuk mempraktekkannya dalam 
kehidupan di sekolah bersama teman maupun dalam kehidupan sehari-harinya, sehingga menjadi kemampuan yang permanen bagi siswa.

\section{Referensi}

Ali, M. (2012). Psikologi Remaja Perkembangan Siswa. Jakarta: Bumi Aksara.

Bimo. (2013). Mahir Mendongeng Membangun dan Mendidik Karakter Anak Melalui Cerita. Yogyakarta: Pro U Media.

Borba, M. (2008). Membangun Kecerdasan Moral. Jakarta: Gramedia Pustaka Utama.

edy, C. w. (2018, Juli 25). KISAH Murid SD Tewas di Tangan Teman Sebangku, Dari Buku hingga Tak Mau Menuntut. Dipetik Juli 20, 2020, dari Tribun Jateng: https://jateng.tribunnews.com/2018/07/25/kisah-murid-sd-tewas-di-tangan-temansebangku-dari-buku-hingga-tak-mau-menuntut

Fadlillah, M. (2014). Pendidikan Karakter Siswa Usia Dini. Yogyakarta: Ar-Ruzz Media.

Fitri, M. (2020). Faktor Yang Mempengaruhi Perkembangan Moral Pada Anak Usia Dini. AlAthfaal, 1.

Helmiati. (2012). Model Pembelajaran . Yogyakarta: Aswaja Pressindi.

Ibda, F. (2012). Pendidikan Moral Anak Melalui Bidang Studi PPKN dan Pendidikan Agama. Arraniry, 338-347.

Kubra, M. (2019). Pengaruh Penerapan Metode Bercerita Terhadap Penanaman Nilai-nilai Moral Anak Usia Dini di Taman Kanak-Kanak Negeri Pertiwi Letta Kabupaten Bantaeng. Pendidikan Anak Usia Dini , 7-8.

Kuswandi, W. (2018, Feb 3). Geotimes. Dipetik Juli 24, 2020, dari Guru budi tewas digebuk, krisis moral siswa: https://geotimes.co.id/opini/guru-budi-tewas-digebuk-krisis-moralsiswa/.

Lalompo, C. T., \& Ester, K. (2017). Metode Pengembangan Moral Dan Nilai Keagamaan Bagi Siswa Usia Dini. Jakarta: PT Grasindo.

Licona, T. (2015). Education For Character. Jakarta: PT. Bumi Aksara.

Madyawati, L. (2016). Strategi Pengembangan Bahasa Pada Anak. Jakarta: Prenada Media Grup.

Majid, A. A. (2008). Mendidik Dengan Cerita. Bandung: Remaja Rosda Karya.

Nata, A. (2008). Perspektif Islam Tentang Strategi Pembelajaran. Jakarta: Kencana Prenada Media Grup.

Pangwijaya, S. (2019, Mei 3). Kasus Terkait Krisis Moral. Dipetik Juli 24, 2020, dari Kompasiana: https://www.kompasiana.com/steven66901/5ccc162d9576oe4381251103/kasus-terkaitkrisis-moral.

putri, H. (2017). Penggunaan Metode Cerita untuk Mengembangkan Nilai Moral Anak TK/SD. Muallimuna , 1. 
Putri, H. (2017). Penggunaan Metode Cerita untuk Mengembangkan Nilai Moral Anak TK/SD. Muallimuna Jurnal Madrasah Ibtidaiyah , 1-9.

Putri, H. (2017). Penggunaan Metode Cerita Untuk Mengembangkan Nilai Moral Anak TK/SD. Jurnal Madrasah Ibtidaiyah , 1-12.

Rong, L. P., \& Noor, N. M. (2019). Digital Storytelling as a Creative Teaching Method in Promoting Secondary School Students Writing Skills. 8.

Ruslan, Elly, R., \& Aini, N. (2016). Penanaman Nilai-Nilai Moral Pada Siswa di SD Negeri Lampeuneurut. PGSD FKIP Unsyaiah , 68-77.

safitri, L. n. (2019). Pengembangan Nilai Agama Dan Moral Melalui Metode Bercerita Pada Anak. Jurnal Ilmiah Tumbuh Kembang Anak Usia Dini , 2502-3519.

Sanjaya, W. (2011). Penelitian Tindakan Kelas. Jakarta: Kencana.

Subur. (2015). Pembelajaran Nilai Moral Berbasis Kisah. Yogyakarta: Kalimedia.

Tafsir, A. (2003). Metodologi Pengajaran Agama Islam. Bandung: Remaja Rosdakarya. 